\title{
Cytokines Induce Urokinase-dependent Adhesion of Human Myeloid Cells A Regulatory Role for Plasminogen Activator Inhibitors
}

\author{
David A. Waltz, Laura Z. Sailor, and Harold A. Chapman \\ Department of Medicine, Children's Hospital, Brigham and Women's Hospital, \\ and Harvard Medical School, Boston, Massachusetts 02115
}

\begin{abstract}
Differentiation of monocytic precursors often results in adhesive properties thought to be important in migration. In this study, the influence of cytokines, known to induce macrophage differentiation, on the adhesiveness of the monocytic cell line U937 was examined in vitro. Despite development of a macrophage morphology, < 5\% of cytokine-stimulated U937 cells were adherent at 24 h. Addition of 1-10 nM urokinase-type plasminogen activator ( $\mathrm{PPA}$ ) induced adherence in the presence of transforming growth factor type beta-1, 1,25-(OH $)_{2}$ vitamin $D_{3}$, granulocyte macrophage colony-stimulating factor, or tumor necrosis factor alpha. uPA-dependent adhesiveness was reversible after $24 \mathrm{~h}$ of stimulation with cytokines and uPA as adherence was prevented by the subsequent addition of anti-uPA antibodies. Adherence induced by diisopropylfluorophosphate-inactivated uPA was severalfold greater than that seen with active uPA. This difference was largely due to cellsurface turnover of active uPA complexed with plasminogen activator inhibitor (PAI). These data indicate that cytokines prime monocyte progenitors for uPA receptor-mediated signals leading to adherence, continued uPA receptor occupancy is required for adherence, and PAI decreases adherence by promoting clearance of uPA / PAI complexes. Thus the interaction of $\mathrm{UPA}$ and PAI at the cell surface, known to affect extracellular matrix proteolysis and hence myeloid cell migration, also regulates adhesion. The coordinated regulation of these two uPA functions by PAI may enhance the migratory potential of monocytic cells. (J. Clin. Invest. 1993. 91:1541-1552.) Key words: urokinase receptor - transforming growth factor type beta $\cdot$ differentiation $\cdot$ monocyte $\cdot$ U937 cells
\end{abstract}

\section{Introduction}

Tissue macrophages are derived from blood-borne monocytes that undergo terminal differentiation during migration from the vascular space (1). A common property of mature monocytes and macrophages is their ability to adhere to endothelial cells (2), plastic surfaces, and components of the extracellular matrix (3). The migration of monocytes and macrophages through the extracellular matrix is thought to be dependent in

Address correspondence to Harold A. Chapman, M.D., Respiratory Division, Department of Medicine, Brigham and Women's Hospital, 75 Francis St., Boston, MA 02115.

Received for publication 1 June 1992 and in revised form 29 October 1992.

J. Clin. Invest.

(C) The American Society for Clinical Investigation, Inc. $0021-9738 / 93 / 04 / 1541 / 12 \$ 2.00$

Volume 91, April 1993, 1541-1552 part on this property of adhesion $(4,5)$. For example, defective cell-surface expression of integrin adhesion molecules by myeloid cells is known to abrogate their migratory ability in vivo (6).

The urokinase/plasmin system is also involved in cell migration. Cells of the monocytic lineage synthesize and secrete urokinase-type plasminogen activator (UPA) ${ }^{1}$ and plasminogen activator inhibitor types 1 (PAI-1) and 2 (PAI-2) and express a high-affinity (low nM) UPA receptor (uPAR) (7-11). Urokinase receptors have been demonstrated on the leading edge of migrating monocytes (12), and endogenously occupied uPA receptors are important in monocyte migration (13). Urokinase, either in solution or bound to UPAR, can be inhibited by PAI-1 and PAI-2 (14-17), and excess PAI-1 has been shown to decrease monocyte migration (18). The presence of active uPA on its cell-surface receptor may provide for focused extracellular proteolysis with dissolution of the extracellular matrix and thus facilitate migration $(19,20)$.

The process of myeloid cell differentiation has been studied in vitro using anchorage-independent human leukemic cell lines, such as HL60, U937, and THP-1, at various stages of maturational arrest $(21,22)$. A number of cytokines modulate $\mathrm{UPA}$ and $\mathrm{UPAR}$ expression and induce macrophage characteristics in these cells (23-30). Although cytokine induction of macrophage-like properties in myeloid leukemic cell lines has been well documented, the acquisition of adhesiveness has been less well characterized. One aim of this study was to explore the effect of cytokines on myeloid cell adhesiveness in vitro.

Recent evidence indicates that uPA binding to its receptor, independent of its catalytic activity, is critical to the differentiation and adhesive response of phorbol diester-stimulated myeloid cell lines (31). We now extend that observation and show that multiple cytokines prime myeloid cells for uPA-mediated signals leading to adhesion. The presence of cell surface-bound uPA is necessary for adherence in this system, although active enzyme is not required. We further provide evidence that PAI reduces adhesiveness by promoting turnover of uPA/PAI complexes from the surface of cytokine-stimulated cells.

\section{Methods}

Reagents. RPMI 1640 was obtained from GIBCO BRL (Gaithersburg, MD); bovine fetal serum from JRH Biosciences (Lenexa, KS); and tissue culture ware from Falcon Labware (Lincoln Park, NJ). The myeloid cell lines U937, THP-1, and HL60 were obtained from the American Type Culture Collection (Rockville, MD). $\left[{ }^{3} \mathrm{H}\right]$ Thymidine,

1. Abbreviations used in this paper: DFP, diisopropylfluorophosphate; $\mathrm{D}_{3}, 1,23-\left(\mathrm{OH}_{2}\right.$ vitamin $\mathrm{D}_{3}$; GPI, glycosyl-phosphatidylinositol; MCSF, macrophage colony-stimulating factor; PAI, plasminogen activator inhibitor; tPA, tissue plasminogen activator; uPA, urokinase; uPAR, urokinase receptor. 
$\left[{ }^{32} \mathrm{P}\right] \mathrm{dATP}$, and $\mathrm{Na}^{125} \mathrm{I}$ were from New England Nuclear (Boston, MA). Recombinant human two-chain high molecular weight uPA and the amino-terminal fragment of uPA, residues 1-143, was a gift of Drs. Jack Henkin and Andrew Mazar, Abbott Laboratories (Abbott Park, IL); a second preparation of uPA was a gift of Dr. Robert Broeze, Collaborative Research (Bedford, MA). 1,25- $(\mathrm{OH})_{2}$ vitamin $\mathrm{D}_{3}$ was a gift of Dr. M. Uskokvic, Hoffmann-LaRoche Laboratories (Nutley, $\mathrm{NJ})$. Human recombinant EGF, IFN-gamma, IL-6, and TGF- $\beta 1$ were from Collaborative Research. Recombinant human GM-CSF and TNF- $\alpha$ were from Genzyme Corp. (Boston, MA). Recombinant human macrophage colony-stimulating factor (M-CSF) was a gift of Dr. Lester Kobzik, Harvard School of Public Health (Boston, MA). Human thrombin was from Enzyme Research Laboratories (South Bend, IN). Boc-valine-leucine-lysine-aminomethylcoumarin was from Peninsula Laboratories, Inc., (Belmont, CA). Affinity-purified human fibrinogen and plasminogen were from KabiVitrum (Stockholm, Sweden). Human PAI-1 purified from HT 1080 fibrosarcoma cell conditioned media was from two sources: a gift of Dr. T. C. Wun of Monsanto Co. (St. Louis, MO); and (\#1090) from American Diagnostica Inc. (Greenwich, CT). Sepharose PD-10 columns were from Pharmacia LKB Biotechnology Inc. (Uppsala, Sweden). Other chemical reagents were from Sigma Immunochemicals (St. Louis, MO).

Cell culture. Cells were cultured in RPMI 1640 supplemented with penicillin $(100 \mathrm{U} / \mathrm{ml})$, streptomycin $(100 \mu \mathrm{g} / \mathrm{ml})$, Hepes $(20 \mathrm{mM}$, $\mathrm{pH} 7.4$ ), and $10 \%$ heat-inactivated fetal bovine serum. Cells were negative for the presence of mycoplasma using an enzymatic detection kit (MycoTect; GIBCO BRL). Culture media were made $48 \mu \mathrm{M}$ in 2-mercaptoethanol in the case of the THP-1 cells. All incubations were at $37^{\circ} \mathrm{C}, 5 \% \mathrm{CO}_{2}$, and cells were plated at $10^{6} / \mathrm{ml}$.

Diisopropylfluorophosphate (DFP) inactivation of $u P A$. uPA was inactivated with $5 \mathrm{mM}$ DFP at room temperature for $1 \mathrm{~h}$ and exhaustively dialyzed (31). DFP-uPA concentration was determined by absorption at $280 \mathrm{~nm}$ and confirmed by ELISA and total protein analysis. DFP treatment resulted in undetectable uPA activity using a plasminogen-dependent fluorometric substrate.

Assay for adherent cells. Adherent cells were assayed as previously described (31) with modifications. Cells at $10^{6} / \mathrm{ml}$ were labeled by incubation with $1 \mu \mathrm{Ci} / \mathrm{ml}\left[{ }^{3} \mathrm{H}\right.$ ] thymidine for $16-24 \mathrm{~h}$ followed by centrifugation at $300 \mathrm{~g}$ for $5 \mathrm{~min}$ at $4^{\circ} \mathrm{C}$. Cells were washed once in serum-free RPMI and resuspended at the original volume in RPMI containing $10 \%$ fetal bovine serum. Cytokines and/or UPA reagents were added to cells and $100 \mu \mathrm{l}$ of cells per well were placed in triplicate in 96-well microtiter plates. After $24 \mathrm{~h}$ of incubation, the contents of control wells were removed for determination of total cpm per well, and the plates were immersed in normal saline. After three rinses, nonadherent cells were flicked out and adherent cells were lysed in $50 \mu \mathrm{l}$ lysis buffer ( $10 \%$ glycerol, $0.2 \%$ sodium dodecyl sulfate, $0.2 \%$ Triton $\mathrm{X}-100$ ) and counted in a liquid-scintillation counter. Adherent cells were also visualized by phase-contrast microscopy; inspection consistently correlated with $\left[{ }^{3} \mathrm{H}\right]$ thymidine incorporation.

Preparation and DFP treatment of active ${ }^{125} \mathrm{I}-u P A$. Urokinase was iodinated by a modification of the chloramine T method (32). $12.5 \mu \mathrm{g}$ of UPA were incubated with $1 \mathrm{mCi}$ of $\mathrm{Na}^{125} \mathrm{I}$ in $0.012 \mathrm{mg} / \mathrm{ml}$ chloramine $\mathrm{T}$ in PBS for $45 \mathrm{~s}$ at room temperature, and the reaction stopped with sodium metabisulfite. Labeled enzyme was separated from unbound ${ }^{125} \mathrm{I}$ by gel chromatography in Sepharose PD-10 in PBS containing $0.25 \mathrm{mg} / \mathrm{ml} \mathrm{BSA}$ as carrier. Active enzyme was then isolated by passage over a $1 \mathrm{ml}$ benzamidine-Sepharose affinity column followed by elution with $0.1 \mathrm{M}$ glycine $\mathrm{HCl}, \mathrm{pH} 4.0$, containing $0.25 \mathrm{mg} / \mathrm{ml}$ BSA. The resultant iodinated enzyme was almost entirely an active 55-kD form as judged by its ability to bind active PAI-1 and by its migration in nonreducing SDS polyacrylamide gels. ${ }^{125} \mathrm{I}$-uPA was inactivated with $5 \mathrm{mM}$ DFP at room temperature overnight to allow unreacted DFP to hydrolyze: SDS-PAGE analysis of ${ }^{125}$ I-DFP-uPA revealed a single band at $55 \mathrm{kD}$ under nonreducing conditions. The concentration of iodinated enzyme was determined by ELISA.

Assay of UPA antigen by ELISA. Determination of uPA antigen was performed using a sandwich-type ELISA employing a monoclonal capture antibody and a polyclonal secondary antibody (33). Analysis of uPA antigen in cell lysate was determined by lysis in $0.5 \%$ Triton $\mathrm{X}-100$ in PBS, pH 7.4, followed by assay in duplicate of $100 \mu \mathrm{l}$ of cell lysate representing $10^{6}$ cells.

Radiolabeled UPA equilibrium-binding studies. Equilibrium binding of ${ }^{125} \mathrm{I}$-uPA was performed as previously described with minor modifications (31). A stock solution of DFP-treated uPA at $300 \mathrm{nM}$ with a specific activity of $864 \mathrm{cpm} / \mathrm{fmol}$ was used. Unstimulated U937 cells $\left(2 \times 10^{5}\right)$ or cells stimulated for $24 \mathrm{~h}$ with various cytokines were incubated in RPMI containing $1 \mathrm{mg} / \mathrm{ml}$ BSA along with iodinated uPA at $4^{\circ} \mathrm{C}$ for $90 \mathrm{~min}$. Cell-bound radioactivity was separated from unbound label by centrifugation through an oil cushion consisting of a 1:1 mixture of silicone oil and dioctylphthalate and counted in a gamma counter. Two types of binding studies were performed. First, U937 cells were incubated without or with various cytokines and a one-point binding assay employing a final uPA concentration of 1.5 $\mathrm{nM}$ was performed for each cell population. Second, saturation-binding curves were obtained with unstimulated cells and cells stimulated with TGF- $\beta 1$ and vitamin $D_{3}$ for $24 \mathrm{~h}$. All assays were performed in triplicate in the absence and presence of $100 \mathrm{M}$ excess unlabeled uPA. Nonspecific binding accounted for $<10 \%$ of total binding. The $K_{d}$ and number of receptor sites per cell were determined by Scatchard analysis.

Polymerase chain reaction. Total cellular RNA was isolated by lysing cells in guanidium isothyocyanate in the presence of sodium sarkosyl and 2-mercaptoethanol according to Chirgwin et al. (34). RNA was precipitated, quantitated by spectroscopy, and stored at $-70^{\circ} \mathrm{C}$. Total cellular RNA, $10 \mu \mathrm{g}$, was reverse transcribed using random hexamer primers in $100 \mu$ l of PCR buffer ( $50 \mathrm{mM} \mathrm{KCl}, 10 \mathrm{mM}$ Tris- $\mathrm{HCl}, \mathrm{pH}$ 8.0, $1.5 \mathrm{mM} \mathrm{MgCl}, 0.001 \%$ gelatin, $0.1 \mathrm{mg} / \mathrm{ml} \mathrm{BSA}$ ) containing $1 \mathrm{mM}$ dNTP (Pharmacia, LKB Biotechnology Inc.), $80 \mathrm{U}$ of RNase inhibitor (Promega Corp., Madison, WI), $4.7 \mu \mathrm{M}$ random hexamers (Amersham Corporation, Arlington Heights, IL), and 1,000 U of murine moloney leukemia virus (GIBCO BRL) at room temperature for 10 min, $42^{\circ} \mathrm{C}$ for $1 \mathrm{~h}, 95^{\circ} \mathrm{C}$ for $5 \mathrm{~min}$. The cDNA was then divided equally and amplified using specific $5^{\prime}$ sense and $3^{\prime}$ antisense 20-mer cDNA primers for UPA, PAI-1, PAI-2, or $\beta$-actin synthesized as previously described (35). PCR was performed for 24 cycles of $94^{\circ} \mathrm{C}$ for $30 \mathrm{~s}$, $55^{\circ} \mathrm{C}$ for $30 \mathrm{~s}$, and $72^{\circ} \mathrm{C}$ for $1 \mathrm{~min}$ in a thermocycler (USA Scientific, Ocala, FL), and the reaction products were analyzed by electrophoresis in agarose gels containing ethidium bromide followed by photography under ultraviolet (UV) illumination as described (35).

Northern analysis. Northern analysis was performed essentially as previously described (36). Total cellular RNA, $25 \mu \mathrm{g}$, from control or stimulated cells prepared as described above for PCR was electrophoresed in a $2 \%$ agarose gel containing $1 \%$ formaldehyde, transferred to a nylon filter (ICN Pharmaceuticals, Inc., Costa Mesa, CA ), and fixed by UV cross-linking. Equivalent amounts of transferred RNA were verified by visualization of $18 \mathrm{~S}$ and $28 \mathrm{~S}$ ribosomal RNA bands under UV light. Double-stranded cDNA probes were prepared for uPA, uPAR, PAI-1, and PAI-2 using PCR product as described ( 35 ) and labeled by random hexamer primer extension using the Multiprime DNA labeling system (Amersham Corporation) according to the manufacturer's directions. Blots were probed using the ${ }^{32} \mathrm{P}$-labeled PCR product followed by autoradiography.

Demonstration of UPA activity by fibrin gel autography. The presence of functional uPA activity was determined by the fibrin gel underlay method (37). Samples containing $10^{6}$ cells were lysed in $100 \mu \mathrm{l}$ nonreduced sample buffer $(62.5 \mathrm{mM}$ Tris $\mathrm{HCl}, \mathrm{pH} 6.8,10 \%$ glycerol, $2 \%$ SDS, $0.013 \%$ bromphenol blue), electrophoresed in $10 \%$ polyacrylamide slab gels with molecular weight standards and urokinase under nonreducing conditions, and laid on $1 \%$ agarose gels containing fibrin and plasminogen. The underlays were incubated at $37^{\circ} \mathrm{C}$ and inspected for bands of lysis at 4 and $24 \mathrm{~h}$.

Fluorometric assay of PAI activity. PAI activity was measured as the ability to inhibit plasminogen-dependent esterolytic activity produced by purified uPA using the plasmin substrate Boc-val-leu-lysaminomethylcoumarin (35). Conditioned media from unstimulated 
U937 cells or cells cultured in the presence of $1 \mathrm{ng} / \mathrm{ml} \mathrm{TGF}-\beta 1$ and 50 $\mathrm{nM}$ vitamin $\mathrm{D}_{3}$ for $24 \mathrm{~h}$ in RPMI containing $1 \mathrm{mg} / \mathrm{ml} \mathrm{BSA}$ were tested in duplicate with or without the addition of $0.5 \mathrm{U} / \mathrm{ml} \mathrm{uPA}$ and/or 7.5 $\mu \mathrm{g} / \mathrm{ml}$ plasminogen. Conditioned media were also subjected to acidification to inactivate PAI-2 (35) and then made $4 \mathrm{M}$ in guanidine $\mathrm{HCl}$ for $10 \mathrm{~min}$ at room temperature to activate PAI-1 (38) followed by successive dialysis against $\mathrm{H}_{2} \mathrm{O}$ and RPMI before testing. Samples were incubated for $30-45 \mathrm{~min}$ at $37^{\circ} \mathrm{C}$ and the reaction stopped by addition of an equal volume of $1 \mathrm{M} \mathrm{NH}_{4}$ acetate, $\mathrm{pH}$ 4.2. Fluorometric activity was determined at an excitation wavelength of $383 \mathrm{~nm}$ and an emission wavelength of $460 \mathrm{~nm}$. Standard curves with purified uPA (0.08-2.5 $\mathrm{U} / \mathrm{ml}$ ) were generated with each assay.

SDS gel electrophoresis and ligand blotting. SDS gel electrophoresis in $10 \%$ polyacrylamide under nonreducing conditions and ligand blotting for demonstration of the uPA receptor were performed as previously described with modifications (32). Total membrane preparations ( $30 \mu \mathrm{g}$ total protein) prepared by centrifugation at $100,000 \mathrm{~g}$ of a postnuclear fraction from homogenized stock unstimulated cells or cells stimulated with various cytokines for $24 \mathrm{~h}$ at $10^{6} / \mathrm{ml}$ were electrophoresed, electroblotted, and exposed to DFP-treated iodinated uPA $(0.25 \mathrm{nM})$ followed by autoradiography.

Activation of PAI-1. Purified PAI-1 was activated by acidification in $4 \mathrm{M}$ guanidine $\mathrm{HCl}$ for $10 \mathrm{~min}$ at room temperature (38), and then dialyzed exhaustively against either $100 \mathrm{mM} \mathrm{L}$-arginine $\mathrm{HCl}, \mathrm{pH} 5.5$, or $10 \mathrm{mM}$ sodium acetate, $\mathrm{pH} 5.5$, and stored at $-70^{\circ} \mathrm{C}$. Activity of purified PAI- 1 was assessed by the ability to abrogate the plasminogendependent fluorometric activity of active uPA after incubation at room temperature for $60 \mathrm{~min}$.

Antibodies. Goat anti-rabbit alkaline phosphatase was from Kirkegaard \& Perry Laboratories, Inc. (Gaithersburg, MD). Murine monoclonal anti-uPA directed against the active site (377, 392, and 394) and the A-chain (3921), murine monoclonal anti-tissue plasminogen activator (tPA) (374b), and polyclonal goat anti-PAI-1 (395G) and antiPAI-2 (375G) were from American Diagnostica (Greenwich, CT). As determined by the manufacturer, $1 \mathrm{mg}$ of goat anti-PAI-1 antibody inhibits $\sim 1,000$ IU PAI-1. The neutralizing ability of goat anti-PAI-2 antibody was determined by a fibrin plate method (32). Preincubation of PAI-2 with $12.5-100 \mu \mathrm{g} / \mathrm{ml}$ of PAI-2 antibodies before placement in the fibrin plate resulted in increasing inhibition of PAI-2 activity. At the $50 \%$ inhibition point, $1 \mathrm{mg}$ of PAI-2 antibodies inhibits $\sim 2.5 \mathrm{IU}$ PAI-2. Thus PAI-2 antibodies were much less potent than PAI-1 antibodies at neutralizing PAI activity. Polyclonal rabbit anti-uPA was from Alpha Therapeutic Corp. (Los Angeles, CA). Monospecificity of the polyclonal rabbit anti-uPA antibodies was determined by immunoblotting of whole-cell lysates from unstimulated U937 cells or cells stimulated for $24 \mathrm{~h}$ with $16 \mathrm{nM}$ PMA or $1 \mathrm{ng} / \mathrm{ml}$ TGF- $\beta 1$ and $50 \mathrm{nM}$ vitamin $D_{3}$. Whole-cell lysates from $8 \times 10^{6}$ cells were fractionated by SDS-PAGE, blotted, and exposed to polyclonal uPA antibodies followed by iodinated goat anti-rabbit IgG. Autoradiography revealed the only bands to be consistent with the 55-kD form of uPA in both the PMA- and TGF- $\beta 1 / D_{3}$-treated cells.

Acid treatment of fetal bovine serum. Fetal bovine serum was titrated to $\mathrm{pH} 3.0$ with $1 \mathrm{M} \mathrm{HCl}$, incubated for $60 \mathrm{~min}$, and neutralized to $\mathrm{pH} 7.4$ with $1 \mathrm{M} \mathrm{NaOH}$ to inactivate fibrinolytic inhibitors as previously described (39).

Determination of ${ }^{125}$ I- $u$ PA turnover. 1-ml aliquots of U937 cells at $10^{6} / \mathrm{ml}$ were incubated in RPMI containing $10 \%$ heat-inactivated or acid-treated fetal bovine serum along with cytokines and iodinated uPA in 24-well tissue culture plates for 2 or $24 \mathrm{~h}$. Cells and media were removed from the wells by vigorous pipetting and conditioned media were isolated by centrifugation. The cell pellet was washed twice in 250 $\mu \mathrm{l}$ cold PBS and resuspended in acid buffer $(50 \mathrm{mM}$ glycine $\mathrm{HCl}, 0.1 \mathrm{M}$ $\mathrm{NaCl}, \mathrm{pH} 3.0$ ) for $3 \mathrm{~min}$ followed by the addition of $100 \mu \mathrm{l}$ of neutralizing buffer (0.5 M Hepes, $0.1 \mathrm{M} \mathrm{NaCl}, \mathrm{pH} 7.5$ ) (40). The acid wash supernatant was obtained by centrifugation and the cell pellet was lysed in $200 \mu \mathrm{l}$ nonreduced sample buffer. Aliquots of conditioned media, acid wash supernatant, and cell lysate were analyzed by liquid-scintillation counting and by PAGE under nonreducing conditions followed by autoradiography. Preliminary experiments demonstrated that specific binding of iodinated UPA and DFP-uPA to U937 cells was roughly equivalent as determined by measurement of cell-associated radioactivity after incubation at $4^{\circ} \mathrm{C}$ for $1 \mathrm{~h}$ in the absence or presence of excess ( $23 \mathrm{nM}$ ) unlabeled uPA.

Statistical analysis. Two-tailed Student's $t$ test was performed for comparison of paired mean experimental values (41).

\section{Results}

Cytokines induce uPA-dependent adherence in U937 cells. Previous reports indicate that the cytokines TGF- $\beta$ and vitamin $D_{3}$ promote differentiation of myeloid cells in vitro $(23,29)$. Our initial experience indicated that although culture of U937 cells for $24 \mathrm{~h}$ with $1 \mathrm{ng} / \mathrm{ml}$ TGF- $\beta 1$ and $50 \mathrm{nM}$ vitamin $D_{3}$ $\left(\mathrm{TGF}-\beta 1 / \mathrm{D}_{3}\right.$ ) resulted in a morphologically differentiated phenotype, virtually none of these stimulated cells were adherent to serum-coated tissue culture plastic. However, the addition of exogenous uPA at the time of stimulation resulted in a marked increase in adherent cells at $24 \mathrm{~h}$. Preincubation of cells with uPA for $24 \mathrm{~h}$ followed by washing and stimulation with TGF$\beta 1 / D_{3}$ for an additional $24 \mathrm{~h}$ resulted in adherence similar to that induced by cytokines alone. Preliminary experiments revealed that catalytically inactive DFP-uPA had a maximal effect at $10 \mathrm{nM}$, and this concentration was used for the majority of experiments in this study.

In addition to TGF- $\beta 1$ and vitamin $D_{3}$, IFN-gamma ( 25 , 28), IL-6 (42), GM-CSF (26, 27), M-CSF (43), and TNF- $\alpha$ (25) have all been shown to promote monocytic cell differentiation. The adherence of $U 937$ cells cultured in the presence of these cytokines with or without uPA for $24 \mathrm{~h}$ was determined (Table I). The cytokine concentrations indicated were at least a $\log$ over that required to induce a maximal effect, i.e., similar uPA-dependent adherence was seen with a 10 -fold lower concentration, with adherence decreasing with diminishing cytokine concentrations below that point. In the absence of uPA there was little adherence noted with any of the cytokines. Adherence of unstimulated cells was modestly enhanced by exogenous uPA alone. The combination of TGF- $\beta 1 / \mathrm{D}_{3}$ was more effective than any other single cytokine or any cytokine combined with vitamin $\mathrm{D}_{3}$ (data not shown) at inducing uPA-dependent adherence. Stimulation with GM-CSF, TGF- $\beta 1$, vita$\min \mathrm{D}_{3}$, and TNF- $\alpha$ all resulted in adherence above control. IFN-gamma, IL-6, and M-CSF did not increase uPA-dependent adherence over that of UPA alone. TGF- $\beta 1 / D_{3}$ stimulation of the myeloid cell lines THP-1 and HL60 also resulted in the induction of uPA-dependent adherence (data not shown), demonstrating generalization of this phenomenon to other myeloid cell lines. The uPA-dependent response was not due to contamination by endotoxin, as minimal adherence was seen at $24 \mathrm{~h}$ in the presence of TGF- $\beta 1 / \mathrm{D}_{3}$ and $100 \mathrm{ng} / \mathrm{ml} \mathrm{LPS}$.

Equilibrium-binding studies using radiolabeled uPA were performed to determine if cytokine-induced increases in uPAdependent adherence correlated with increases in cell-surface uPA binding. Preliminary studies indicated that, as previously reported, U937 cells express specific saturable uPA receptors (data not shown). Relative uPA binding to U937 cells after 24 $\mathrm{h}$ of stimulation with cytokines as determined by a one-point assay method are listed in Table I. TGF- $\beta 1$, TGF- $\beta 1 / D_{3}$, GMCSF, and TNF- $\alpha$ all induced an increase in uPA binding as well as uPA-dependent adherence. However, the relative magnitude of increase in uPA binding did not strictly correlate with 
Table I. Effect of Cytokines on U937 Cell UPA Binding and uPA-dependent Adherence

\begin{tabular}{|c|c|c|c|c|c|c|c|}
\hline \multirow[b]{2}{*}{ Cytokine } & \multirow[b]{2}{*}{ Concentration } & \multicolumn{4}{|c|}{ Percent maximal adherence } & \multirow{2}{*}{$\begin{array}{c}\text { uPA } \\
\text { binding }\end{array}$} & \multirow[b]{2}{*}{ SD } \\
\hline & & -uPA & SD & +uPA & SD & & \\
\hline None & - & 0.8 & $(0.2)$ & 15.5 & (8.4) & 1 & \\
\hline Vitamin $D_{3}$ & $50 \mathrm{nM}$ & 1.2 & $(0.6)$ & 37.7 & $(22.7)$ & 0.9 & $(0.01)$ \\
\hline TGF- $\beta 1$ & $1 \mathrm{ng} / \mathrm{ml}$ & 1.0 & $(0.4)$ & 41.2 & $(22.1)$ & 1.6 & $(0.05)$ \\
\hline TGF $-\beta 1 / D_{3}$ & $1 \mathrm{ng} / \mathrm{ml}$ & 1.9 & $(0.9)$ & 100 & $(34.5)$ & 3.4 & $(0.76)$ \\
\hline IFN-gamma & $1,000 \mathrm{U} / \mathrm{ml}$ & 0.6 & $(0.1)$ & 12.9 & (5.8) & 0.9 & $(0.12)$ \\
\hline IL-6 & $100 \mathrm{ng} / \mathrm{ml}$ & 0.7 & $(0.1)$ & 17.8 & (6.3) & ND & \\
\hline GM-CSF & $1,000 \mathrm{U} / \mathrm{ml}$ & 1.4 & $(0.5)$ & 60.2 & $(12.0)$ & 1.6 & $(0.16)$ \\
\hline M-CSF & $100 \mathrm{ng} / \mathrm{ml}$ & 0.7 & $(0.1)$ & 9.8 & $(5.2)$ & 0.9 & $(0.43)$ \\
\hline TNF- $\alpha$ & $10 \mathrm{U} / \mathrm{ml}$ & 0.9 & $(0.1)$ & 36.4 & $(14.2)$ & 1.9 & $(0.81)$ \\
\hline
\end{tabular}

U937 cells prelabeled with $\left[{ }^{3} \mathrm{H}\right]$ thymidine were incubated at $10^{6} / \mathrm{ml}$ without or with cytokines in the absence or presence of $10 \mathrm{nM}$ DFP-uPA for $24 \mathrm{~h}$ at $37^{\circ} \mathrm{C}$. Adherence was quantified by measuring residual radioactivity in wells after washing to remove nonadherent cells. Results from three separate experiments each performed in triplicate (two experiments in the case of IL-6) are expressed as the mean adherence relative to TGF- $\beta 1 / D_{3} / D F P-u P A$. For measurement of uPA binding, unstimulated U937 cells or cells stimulated with cytokines for $24 \mathrm{~h}$ at the indicated concentrations were incubated for $90 \mathrm{~min}$ at $4^{\circ} \mathrm{C}$ with $1.5 \mathrm{nM}{ }^{125} \mathrm{I}$-DFP-uPA in the absence and presence of $100 \mathrm{M}$ excess cold uPA. Cells were then spun through oil to separate free ligand and cell-associated label was counted in a gamma counter. Data are expressed as specific uPA binding relative to unstimulated cells. ND, not done.

the magnitude of increase in adherence, as seen by examining the values for TGF- $\beta 1$ and GM-CSF. Indeed, although vitamin $\mathrm{D}_{3}$ increased uPA-dependent adherence, it did not alter uPA binding over control. IFN-gamma and M-CSF had no effect on either adherence or uPA binding.

In general $<5 \%$ of control unstimulated cells or cells incubated with cytokines alone were adherent after washing. Adherence increased to an average of $50 \%$ with a range of $25-90 \%$ in wells containing cells stimulated with TGF- $\beta 1 / D_{3}$ and uPA. In part this variability appeared to be due to a gradual loss of responsiveness with time in culture and for this reason cells having undergone between 2 and 11 weekly passages were used for the subsequent work.

We next sought to determine if morphologically differentiated yet nonadherent myeloid cells $24 \mathrm{~h}$ after stimulation with cytokines would respond to uPA by becoming adherent. U937 and THP-1 cells were cultured in the presence of TGF$\beta 1 / D_{3}$ and then $10 \mathrm{nM}$ uPA was added to the cell culture at 24 $h$. Adhesion occurred within minutes of the addition of uPA in these cytokine-stimulated cells (Fig. $1 A$ ). Adhesion was accompanied by changes in cellular morphology (Fig. $1 \mathrm{~B}$ ). 60 min after the addition of uPA, cells were spread and had numerous cytoplasmic projections. The morphologic changes were more striking in THP-1 cells (shown in Fig. $1 B$ ) than in U937 cells, whereas adherence was similar (data not shown).

Examination of the UPA axis in cytokine-stimulated U937 cells. U937 cells are known to constitutively express uPA (7), cell-surface $\mathrm{UPA}$ receptor (10), and the uPA-specific inhibitor PAI-2 (7). No information on the effect of TGF- $\beta 1$ on expression of these proteins by $\mathrm{U} 937$ cells is currently available. Because the uPA-dependent adherent response was most pronounced in TGF- $\beta 1 / D_{3}$-stimulated U937 cells (Table I) we explored the regulation of UPA, its inhibitors, and its receptor in these cells. The presence of messenger RNA transcripts for uPA, PAI-1, and PAI-2 was determined by PCR (Fig. $2 A$ ). The presence of PCR product for reverse-transcribed uPA
mRNA was demonstrated under all conditions. Although PAI1 mRNA was undetectable in control cells and in response to vitamin $D_{3}$, mRNA was clearly evident in response to TGF- $\beta 1$ and TGF- $\beta 1 / D_{3}$. In other experiments, PAI- 1 mRNA could be detected by $4 \mathrm{~h}$ after stimulation. These findings were also seen in THP-1 cells stimulated in a similar manner: PAI-1 mRNA was not detected by PCR in unstimulated cells, whereas a strong signal was evident after TGF- $\beta 1 / D_{3}$ stimulation (data not shown). PAI-2 mRNA was present in control cells and in cells treated with vitamin $D_{3}$ or TGF- $\beta 1$ and was clearly reduced in TGF- $\beta 1 / \mathrm{D}_{3}$ cells at $24 \mathrm{~h}$ : Indeed, reduced or absent PAI- 2 mRNA was also noted by $4 \mathrm{~h}$ after stimulation.

Quantitation of messenger RNA for UPAR, uPA, and PAI1 by Northern analysis is shown in Fig. $2 B$. Phorbol ester, a known inducer of uPAR mRNA in U937 cells (44), was included for comparison (lane 2). UPAR mRNA was present in stock unstimulated cells (lane 1 ) and vitamin $\mathrm{D}_{3}$-stimulated cells (lane 3 ) in similar amounts, and increased by PMA, TGF$\beta 1$ (lane 4), and TGF- $\beta 1 / D_{3}$ (lane 5). Stimulation with TGF$\beta 1 / D_{3}$ had a modest effect in upregulating uPA mRNA whereas both known transcripts for PAI-1 were strongly upregulated by TGF- $\beta 1 / D_{3}$, confirming the PCR data shown in Fig. $2 A$. PAI- 2 mRNA was undetectable by Northern analysis after TGF- $\beta 1 / D_{3}$ stimulation (data not shown), verifying the PCR results.

Assays were performed to confirm the presence of functional UPA, PAI, and UPAR. Urokinase antigen levels detected by ELISA in lysates of cells stimulated with TGF- $\beta 1 / D_{3}$ were similar to those seen in unstimulated cells (data not shown). The presence of functional urokinase activity in cell lysates of cytokine-primed cells was confirmed by fibrin gel underlay. In this assay TGF- $\beta 1 / D_{3}$-stimulated cells had functional uPA activity comparable to that seen in unstimulated cells. As discussed below, endogenously produced uPA is actively turned over in cytokine-stimulated cells; thus measurement of uPA antigen or functional activity at $24 \mathrm{~h}$ may not accurately reflect 

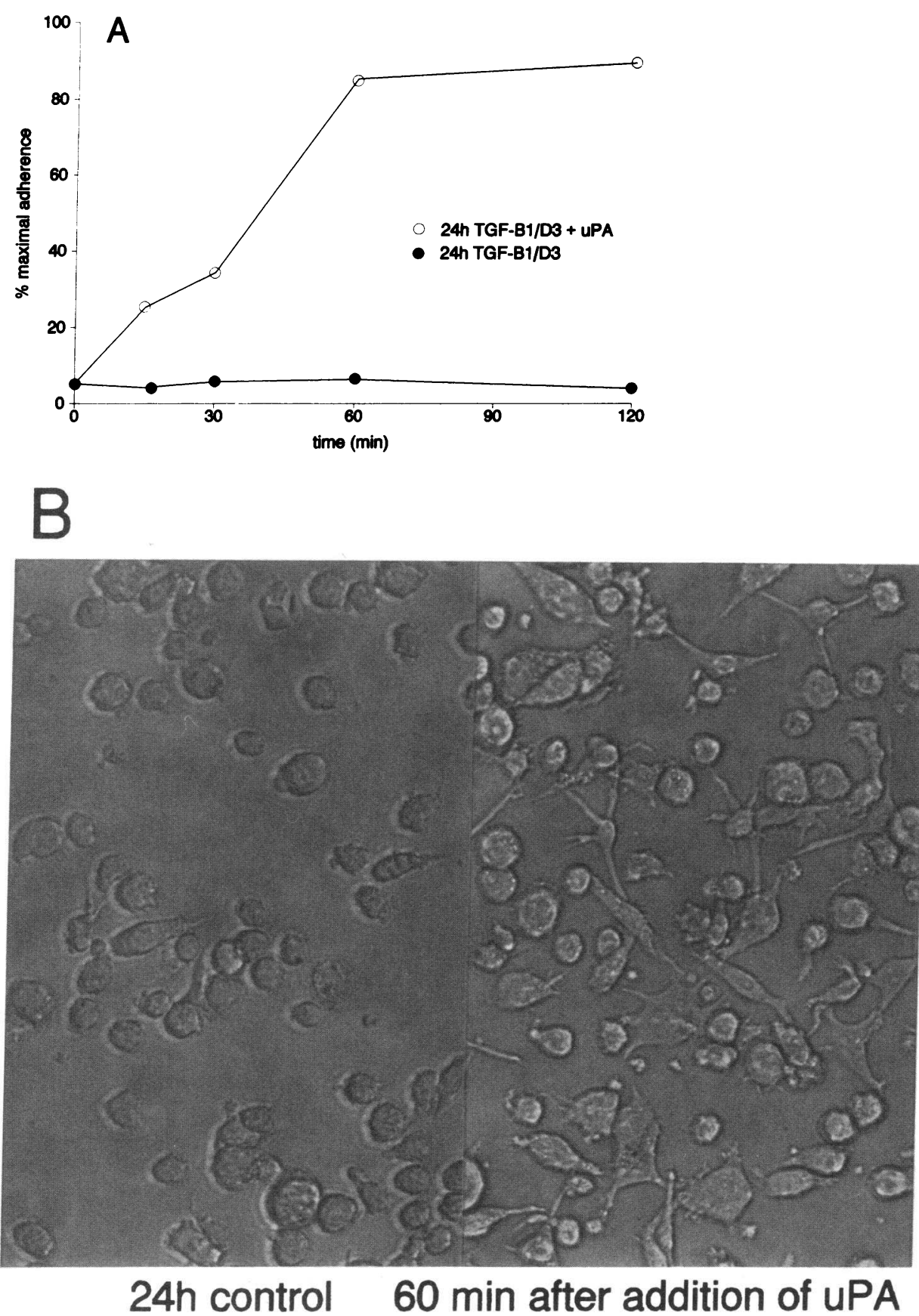

Figure 1. Priming effect of cytokines for uPA responsiveness in myeloid cells. Prelabeled U937 and THP-1 cells were cultured at $10^{6} / \mathrm{ml}$ in the presence of $1 \mathrm{ng} / \mathrm{ml} \mathrm{TGF}-\beta 1$ and $50 \mathrm{nM}$ vitamin $\mathrm{D}_{3}$. At $24 \mathrm{~h}, 10 \mathrm{nM}$ DFP-uPA was added to the cell culture. $(A)$ Adherence after washing at various times in a representative experiment is indicated. Adherence reflects the mean of triplicate determinations of residual radioactivity in wells from a representative experiment and is expressed relative to maximal adherence, the amount of radioactivity present in wells containing cells cultured concurrently with $1 \mathrm{ng} / \mathrm{ml}$ TGF- $\beta 1,50 \mathrm{nM}$ vitamin $\mathrm{D}_{3}$, and $10 \mathrm{nM}$ DFP-uPA for $24 \mathrm{~h}$. Adherence of U937 cells stimulated with TGF- $\beta 1 / D_{3}$ but without addition of DFP-uPA are given for comparison. $(B)$ The photograph illustrates the morphology seen in THP- 1 cells cultured for $24 \mathrm{~h}$ in the presence of $1 \mathrm{ng} / \mathrm{ml} \mathrm{TGF-} \beta 1$ and 50 $\mathrm{nM}$ vitamin $\mathrm{D}_{3}$ before and 60 min after the addition of $10 \mathrm{nM}$ DFP-uPA.

uPA production. This fact may explain the apparent discrepancy of upregulation of uPA mRNA despite no change in uPA antigen or functional activity in TGF- $\beta 1 / \mathrm{D}_{3}$-stimulated as opposed to unstimulated cells. For this reason, no attempt was made to further quantitate uPA expression by these cells.

The presence of functional inhibitor was confirmed by plasminogen-dependent fluorometry. In the absence of exogenous uPA, conditioned media from unstimulated cells or cells stimulated with TGF- $\beta 1 / \mathrm{D}_{3}$ for $24 \mathrm{~h}$ had no plasminogen-dependent fluorometric activity. When incubated with active uPA, both sets of media substantially inhibited urokinase activity. Inhibition was dose dependent. Acidification of conditioned media containing PAI inactivates PAI-2 (35) whereas detergent treatment activates PAI-1 (38). The inhibitor activity of unstimulated conditioned media was completely abrogated by acidification and detergent treatment, whereas that of stimulated cells was resistant to these treatments. These physical properties are consistent with the inhibitory activity of control medium being PAI- 2 and that in TGF- $\beta 1 / D_{3}$ medium being mostly PAI-1, as was also suggested by the mRNA analyses (Fig. 2). Because of the tendency of PAI-1 to become latent at $37^{\circ} \mathrm{C}$, the inhibitor activity was not further quantified.

The presence of functional uPA receptor in cytokine-stimulated myeloid cells was confirmed by ligand blotting (Fig. 3 ). 


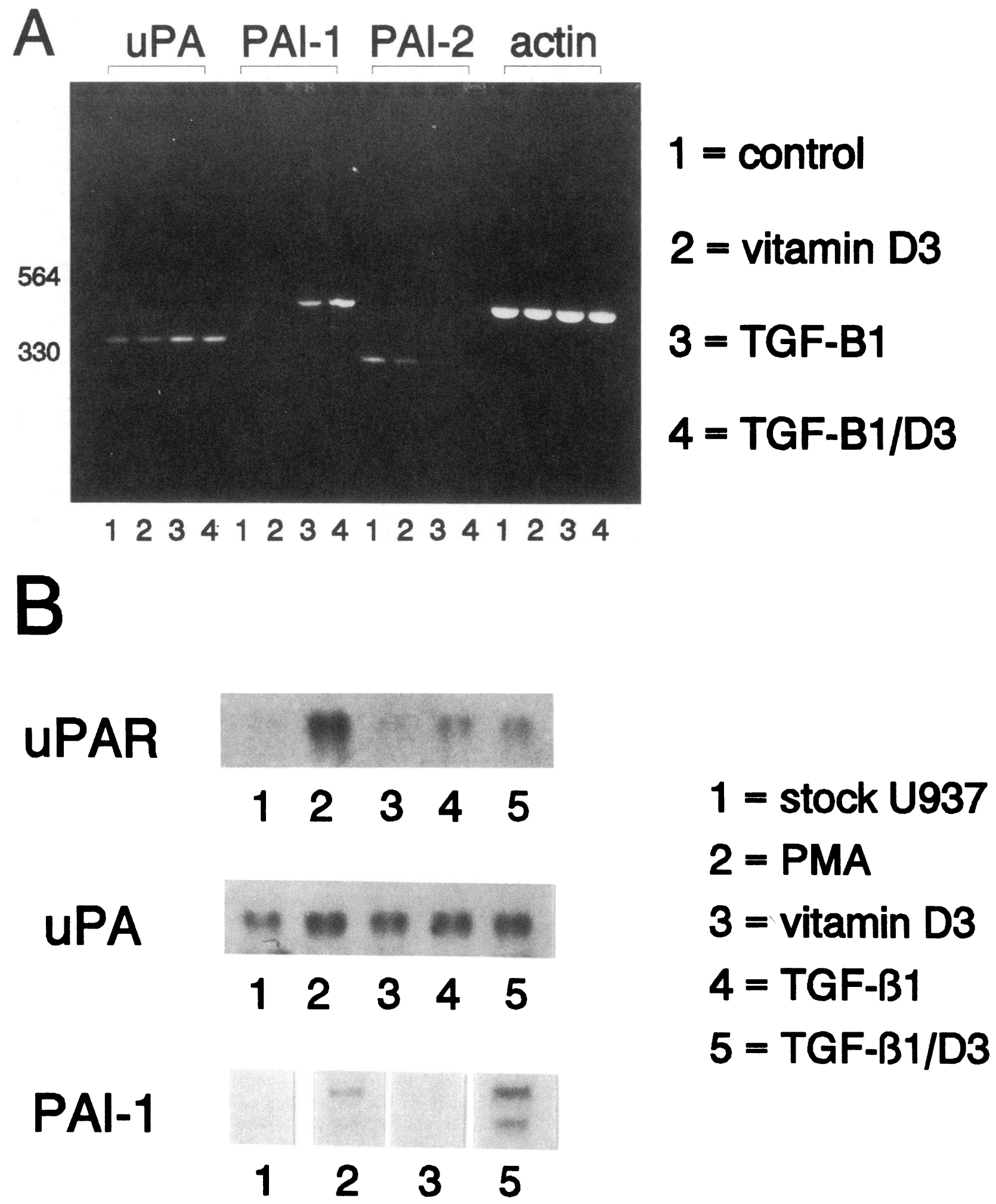

Figure 2. Effects of TGF- $\beta 1 / D_{3}$ on uPA, PAI-1, PAI-2, and uPA-R mRNA in U937 cells. $(A)$ PCR. Total cellular RNA from stock U937 cells and cells cultured in the presence of $50 \mathrm{nM}$ vitamin $D_{3}, 1 \mathrm{ng} / \mathrm{ml}$ TGF- $\beta 1$, and a combination of TGF- $\beta 1$ and vitamin $D_{3}$ for $24 \mathrm{~h}$ was reverse transcribed using random primers. The resultant cDNA was amplified by PCR using specific primers for uPA, PAI-1, PAI-2, and $\beta$-actin. The predicted sizes of the PCR transcripts were $360,497,299$, and $493 \mathrm{bp}$ for uPA, PAI-1, PAI-2, and $\beta$-actin, respectively. The size of DNA standards (in bp) is given to the left of the figure. $(B)$ Northern analysis. Total cellular RNA ( $10 \mu \mathrm{g}$ ) from unstimulated cells or cells cultured in the presence of $16 \mathrm{nM}$ PMA or vitamin $D_{3}$, TGF- $\beta 1$, or TGF- $\beta 1 / \mathrm{D}_{3}$ as indicated above for $24 \mathrm{~h}$ was electrophoresed, blotted, and probed with radiolabeled cDNA for UPAR, uPA, and PAI-1. Equivalent loading of RNA was verified by direct visualization under UV light. 
The amount of membrane-associated uPA receptor in stock unstimulated cells can be seen in lane 1 . After PMA stimulation, uPAR expression is markedly increased (lane 2); phorbol ester stimulation has previously been shown to strongly upregulate $\operatorname{uPAR}(44,45)$. The amount of UPAR was also increased by stimulation with TGF- $\beta 1 / \mathrm{D}_{3}$ (lane 3 ) and TNF- $\alpha$ (lane 5 ) but essentially unchanged by M-CSF (lane 4 ). This observation parallels the adherence assay data shown in Table I in that TGF- $\beta 1 / \mathrm{D}_{3}$ and TNF- $\alpha$ but not M-CSF increase uPAdependent adherence over that seen in control cells. Relative UPAR expression as determined by densitometry correlated well with relative uPA binding ( Table I) in the case of TGF- $\beta 1$ / $\mathrm{D}_{3}$, although a greater increase in functional receptor was seen by ligand blot than by binding in TNF- $\alpha$-stimulated cells. This may reflect the fact that the ligand blot measures total cellular uPAR whereas the binding studies only examine unoccupied cell-surface receptors. In summary, by $24 \mathrm{~h}$, TGF- $\beta 1 / \mathrm{D}_{3}$ stimulation of U937 cells increased UPA receptor and PAI-1 expression, downregulated PAI-2 expression, and had no detectable effect on uPA expression.

Urokinase-dependent adherence is specific and reversible. We explored the uPA-dependent adherence of TGF- $\beta 1 / \mathrm{D}_{3}-$ stimulated U937 cells and sought to determine the specificity of this response for uPA receptor binding. Both uPA and DFPinactivated uPA induced adherence in a dose-dependent manner (Fig. 4). DFP-uPA was severalfold more potent than active uPA at inducing half-maximal adherence. An amino-terminal fragment of uPA (ATF), comprising amino acid residues 1-143 and containing the receptor-binding domain but lacking the catalytic domain, was as potent as DFP-uPA at inducing adherence. In contrast, the inclusion of EGF, which has a receptor binding domain homologous to that of uPA (46), or thrombin with TGF- $\beta 1 / D_{3}$ had no effect on adherence.

Scatchard analyses of saturation-binding studies employing radiolabeled DFP-inactivated UPA were performed to determine the affinity and number of cell-surface uPA binding sites.

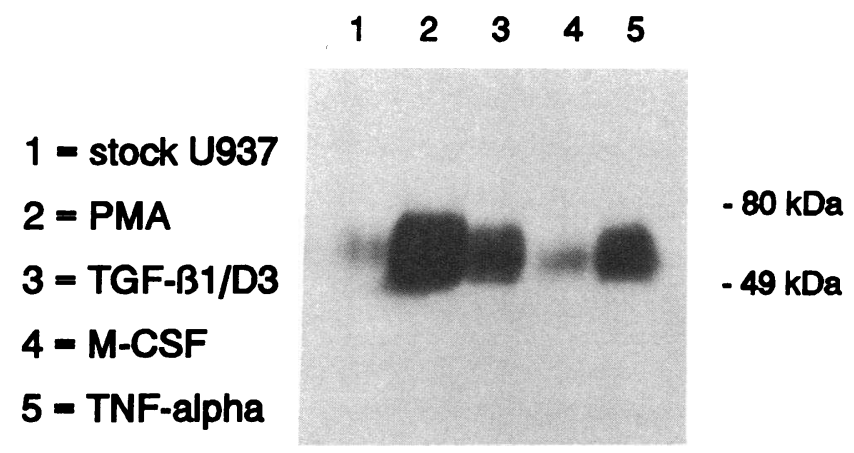

\section{Relative Density: $\quad 1 \quad 9.8 \quad 3.91 .35 .4$}

Figure 3. Demonstration of functional uPA receptor as determined by ligand blotting. Total membrane preparations ( $30 \mu \mathrm{g}$ per lane) from stock U937 cells or cells cultured for $24 \mathrm{~h}$ in the presence of $16 \mathrm{nM}$ PMA; $1 \mathrm{ng} / \mathrm{ml}$ TGF- $\beta 1$ and $50 \mathrm{nM}$ vitamin $\mathrm{D}_{3} ; 100 \mathrm{ng} / \mathrm{ml} \mathrm{M}-\mathrm{CSF}$; or $10 \mathrm{U} / \mathrm{mL}$ TNF- $\alpha$ were electrophoresed, electroblotted, and exposed to $0.25 \mathrm{nM}$ DFP-treated ${ }^{125} \mathrm{I}$-uPA followed by autoradiography. The migration of molecular weight standards is indicated along the right edge of the figure. Relative binding as reflected by computeraided densitometry is shown under each lane.

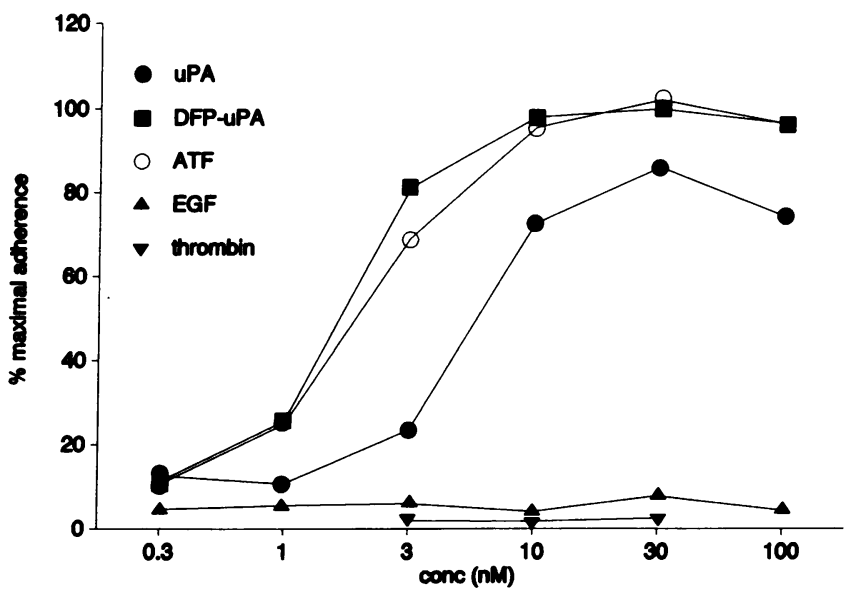

Figure 4. Dose-response relationship of uPA-induced adherence in TGF- $\beta 1 / D_{3}$-stimulated U937 cells. U937 cells were cultured in the presence of $50 \mathrm{nM}$ vitamin $\mathrm{D}_{3}$ and $1 \mathrm{ng} / \mathrm{ml}$ TGF- $\beta 1$ along with $\mathrm{uPA}$, DFP-uPA, ATF, EGF, or thrombin at the indicated concentrations for $24 \mathrm{~h}$ and adherence was determined. Adherence is expressed relative to the adherence of cells cultured in the presence of $30 \mathrm{nM} \mathrm{DFP}$ uPA along with TGF- $\beta 1 / D_{3}$ (maximal adherence) and results reflect the mean of triplicate determinations from a representative experiment.

Both stock unstimulated U937 cells and cells cultured for $24 \mathrm{~h}$ in the presence of $1 \mathrm{ng} / \mathrm{ml}$ TGF- $\beta 1$ and $50 \mathrm{nM}$ vitamin $D_{3}$ had a $K_{\mathrm{d}}$ of $0.33 \mathrm{nM}$ for uPA binding. Stock cells had $\approx 11,000$ binding sites per cell; this rose to $\approx 41,000$ after TGF- $\beta 1 / D_{3}$ stimulation. The concentration of DFP-uPA needed for halfmaximal adherence, $2 \mathrm{nM}$ as seen in Fig. 4, was higher than the $K_{\mathrm{d}}$ for binding at $24 \mathrm{~h}$ : This may be due in part to cell-surface turnover of the enzyme over the course of the 24-h stimulation as presented below. Indeed, half-maximal adherence of cells stimulated with $1 \mathrm{ng} / \mathrm{ml}$ TGF- $\beta 1$ and $50 \mathrm{nM}$ vitamin $D_{3}$ for 24 $\mathrm{h}$ and then exposed to DFP-uPA as in Fig. 1 was induced by 0.1-0.3 nM DFP-uPA (data not shown), correlating well with the measured binding affinity.

As previously reported (31), polyclonal anti-uPA antibodies known to block receptor binding blocked the adherent response to uPA (Fig. 5). A murine mAb directed against the A-chain of uPA (which contains the receptor-binding domain) also blocked adherence. In contrast, uPA-induced adherence was increased by a neutralizing $\mathrm{mAb}$ directed against the active site of UPA that recognizes receptor-bound UPA and thus may not interfere with uPA binding to uPAR. A mAb against tPA, included as a control, had no effect on adherence.

Taken together, the data from Figs. 4 and 5 indicate that the adherent response is specific for uPA binding to its receptor and does not involve active uPA-dependent proteolysis. This conclusion supports earlier work showing an autocrine role for the receptor-binding domain of uPA in phorbol diester-mediated myeloid cell differentiation (31).

The possibility that uPA-dependent adhesiveness is reversible was considered. U937 cells were cultured in the presence of $1 \mathrm{ng} / \mathrm{ml}$ TGF- $\beta 1,50 \mathrm{nM}$ vitamin $\mathrm{D}_{3}$, and $3 \mathrm{nM}$ uPA for $24 \mathrm{~h}$ on Teflon surfaces to prevent adhesion. $60 \mathrm{~min}$ after placement on tissue culture plastic, cells were adherent (data not shown). Addition of $0.25 \mathrm{mg} / \mathrm{ml}$ polyclonal rabbit anti-uPA or $30 \mu \mathrm{g} /$ 


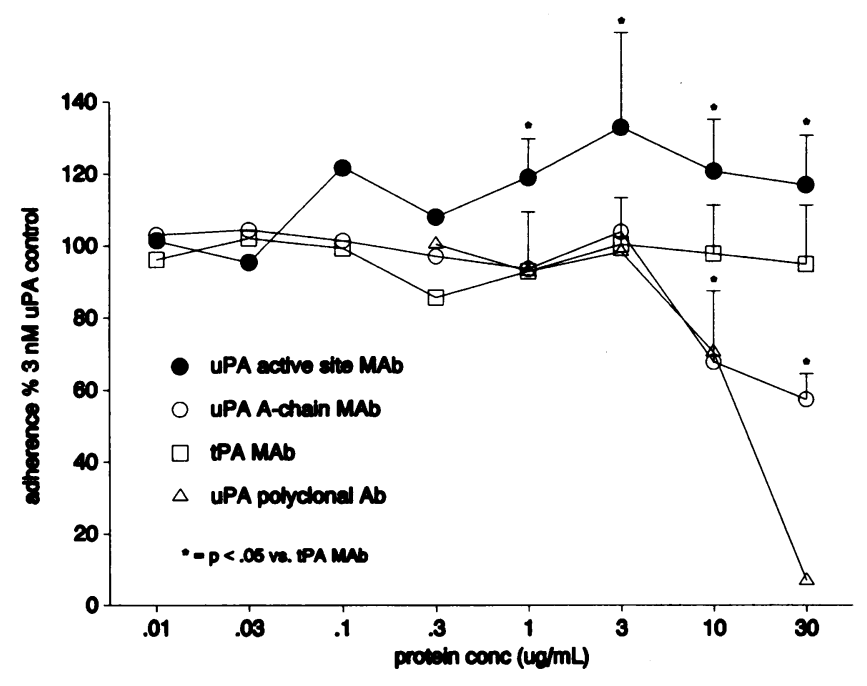

Figure 5. Effect of anti-uPA antibodies on uPA-dependent adherence of TGF- $\beta 1 / D_{3}$-stimulated U937 cells. U937 cells were cultured in the presence of $1 \mathrm{ng} / \mathrm{ml}$ TGF- $\beta 1,50 \mathrm{nM}$ vitamin $D_{3}$, and $3 \mathrm{nM} \mathrm{uPA}$ without or with antibodies for $24 \mathrm{~h}$ and adherence was determined. Murine mAbs directed against the active site of uPA (a neutralizing antibody), the A-chain of uPA (containing the receptor binding domain), and tPA as well as rabbit polyclonal anti-uPA were used in the indicated concentrations. Adherence is expressed relative to TGF- $\beta 1 / D_{3} / \mathrm{uPA}$-treated cells cultured in the absence of antibodies and reflects the mean of triplicate determinations from two representative experiments. Error bars representing the standard deviation are given for $\mathrm{uPA} \mathrm{mAb}$ concentrations with adherence significantly different $(P<0.05)$ than tPA mAb.

$\mathrm{ml} \mathrm{A}$-chain $\mathrm{mAb}$ at the time of placement on plastic prevented adherence whereas $0.25 \mathrm{mg} / \mathrm{ml}$ nonimmune rabbit serum and $30 \mu \mathrm{g} / \mathrm{ml}$ active-site $\mathrm{mAb}$ had no effect. Prevention of adherence by anti-uPA could be overcome by the subsequent addition ( $1 \mathrm{~h}$ later) of $100 \mathrm{nM}$ uPA. Similar findings were observed in cells cultured for $24 \mathrm{~h}$ in the presence of TGF- $\beta 1 / \mathrm{D}_{3}$ and uPA and then subjected to acid treatment to remove cell-surface uPA (40). Although initially nonadherent $60 \mathrm{~min}$ after placement on plastic, these surface uPA-depleted cells became adherent upon addition of 10 nM uPA (data not shown). These results demonstrate that the adherence of cytokineprimed cells is dependent on the continued presence of cell surface-bound uPA.

$P A I$ affects $U P A$-dependent adherence by increasing clearance of $u P A$ from its receptor. DFP-inactivated uPA was consistently severalfold more effective than active uPA at inducing adherence of cytokine-stimulated cells. In addition, a neutralizing $\mathrm{mAb}$ directed against the active site of uPA increased uPAdependent adherence in these cells. We explored three possible mechanisms for this difference. Plasmin activation by active enzyme may result in proteolytic processing of active uPA or another molecule resulting in decreased adherence. Alternatively, the presence of serum inhibitors in the culture media may bind active uPA and prevent its binding to the UPA receptor. Finally, PAI- 1 is known to bind to receptor-bound UPA (15), the uPA PAI-1 complex has been shown to be internalized and degraded in unstimulated U937 cells (47), uPA/PAI1 turnover is regulated by UPAR (48), and DFP-uPA does not bind PAI-1. As shown above, PAI-1 production is increased in
U937 cells stimulated with TGF- $\beta 1 / D_{3}$. Because adherence requires continued occupancy of the uPA receptor, turnover of uPA/PAI-1 complexes from the cell surface may decrease receptor-mediated signals leading to adherence.

To determine the importance of plasmin activation and serum inhibitors in uPA-dependent adherence, adherence assays analagous to those shown in Fig. 4 were performed in the presence of serum depleted of inhibitors by acid treatment (39). U937 cells stimulated with TGF- $\beta 1 / D_{3}$ along with DFPinactivated uPA ( $3 \mathrm{nM}$ ) under these conditions were adherent at $24 \mathrm{~h}$ whereas active uPA did not induce adherence (data not shown). The addition of the plasmin inhibitor aprotinin (6 $\mu \mathrm{M})$ partially restored the ability of active uPA to promote adherence, although DFP-inactivated uPA remained more effective than active uPA with dose-response curves similar to those shown in Fig. 4. These data indicate that although serum inhibitors and/or a plasmin-dependent process may account for differences between uPA and DFP-uPA under some conditions, DFP-inactivated uPA remains severalfold more effective than active UPA under conditions in which neither mechanism is operative. Thus the possible role of PAI-1 in modulating adhesion was explored.

The effect of PAI-1 complexed with UPA on the adherence of TGF- $\beta 1 / D_{3}$-stimulated U937 cells is shown in Fig. $6 \mathrm{~A}$. In contrast to DFP treatment of UPA, preincubation of UPA with PAI-1, while also completely abrogating the proteolytic activity of UPA, did not enhance the ability of uPA to induce adherence of TGF- $\beta 1 / D_{3}$-stimulated U937 cells. In a similar fashion, uPA incubated with aprotinin was only as effective as uPA alone at inducing adherence, although plasmin activation was blocked as demonstrated by a fluorometric assay.

The effect of anti-PAI- 1 antibodies on the adherence of TGF- $\beta 1 / D_{3}$-stimulated U937 cells is shown in Fig. 6 B. As stimulation results in downregulation of PAI-2 (Fig. $2 A$ ), anti-PAI-2 antibodies were used as a control IgG. The addition of anti-PAI- 1 resulted in increased adherence as compared with control cells or cells treated with control antibody. The maximal effect of PAI-1 antibodies shown in Fig. $6 \mathrm{~B}$ with 50 $\mu \mathrm{g} / \mathrm{ml}$ was not exceeded by $\leq 400 \mu \mathrm{g} / \mathrm{ml}$ of antibodies whereas PAI-2 antibodies had no effect in this concentration range. The magnitude of the response was small, with $<5 \%$ of cells adhering.

Clearance of uPA/PAI-1 complexes from the cell surface has been documented in unstimulated U937 cells, and this clearance is abrogated by chloroquine, an inhibitor of lysosomal protein degradation (47). We sought to determine if a clearance mechanism is also operative in TGF- $\beta 1 / \mathrm{D}_{3}-$ stimulated cells. The effect of $\mathrm{NH}_{4} \mathrm{Cl}$, which blocks acidification of the lysosomal compartment (49), on the uPA-dependent adherence of U937 cells was determined (Fig. 7). Adherence of control cells and cells incubated with TGF- $\beta 1 / D_{3}$ in the absence or presence of UPA or DFP-inactivated UPA were all enhanced by the addition of $\mathrm{NH}_{4} \mathrm{Cl}$. The enhancing effect seen with active uPA was greater than that seen with DFP-inactivated enzyme, suggesting that lysosomal degradation modulates uPA-dependent adherence. The modest increase in adherence observed in control and DFP-uPA-treated cells may reflect $\mathrm{NH}_{4} \mathrm{Cl}$-induced decreases in turnover of endogenously produced uPA.

We next compared clearance of active and DFP-inactivated uPA in cytokine-stimulated myeloid cells (Fig. 8). Iodinated uPA or DFP-uPA, in concentrations lower than that required 

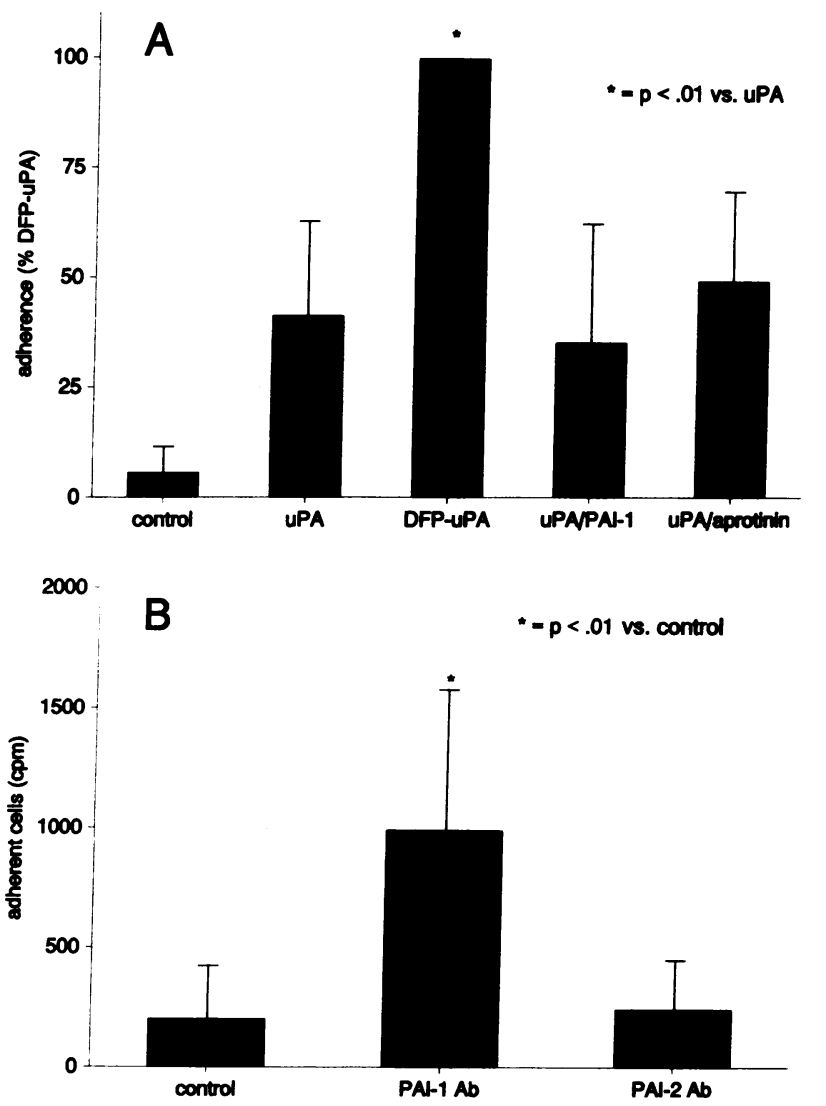

Figure 6. Effects of uPA and plasmin inhibitors and PAI-1 and PAI-2 antibodies on TGF- $\beta 1 / D_{3}$ U937 cell adherence. $(A)$ PAI- 1 was activated as described and $6 \mathrm{nM}$ uPA incubated in the presence or absence of active PAI-1 $(1,250 \mathrm{U} / \mathrm{ml})$ or aprotinin $(12 \mu \mathrm{M})$. The uPA samples were then added to U937 cells to yield a final concentration of $3 \mathrm{nM}$ uPA and $6 \mu \mathrm{M}$ aprotinin. DFP-uPA, $6 \mathrm{nM}$, was sham incubated and added to cell culture under similar conditions. Cells were cultured for $24 \mathrm{~h}$ and adherence was determined. The mean ( \pm SD) adherence of eight separate experiments (four experiments in the case of aprotinin ) each performed in triplicate are expressed relative to the adherence of cells cultured with TGF- $\beta 1 / D_{3} /$ DFP-uPA. $(B)$ Neutralizing goat anti-PAI-1 or anti-PAI-2 antibodies at $50 \mu \mathrm{g} / \mathrm{ml}$ were added to U937 cell culture at the time of stimulation with 1 $\mathrm{ng} / \mathrm{ml}$ TGF- $\beta 1$ and $50 \mathrm{nM}$ vitamin $D_{3}$ and adherence determined at $24 \mathrm{~h}$. The results shown represent the mean $( \pm S D)$ from three separate experiments each performed in triplicate.

to induce adherence at $24 \mathrm{~h}$ (Fig. 3), was added to U937 cells along with TGF- $\beta 1 / D_{3}$ and conditioned media and cell-surface elutable enzyme subsequently examined by SDS-PAGE. The clearance of uPA and DFP-uPA from conditioned media at 2 and $24 \mathrm{~h}$ of culture is illustrated in Fig. $8 \mathrm{~A}$. The $55-\mathrm{kD}$ purified form of iodinated uPA incubated in cell-free medium is shown in lane 9. In the presence of cells, active uPA forms a complex of $\approx 90 \mathrm{kD}$ at $2 \mathrm{~h}$ (lane 1 ); the formation of this complex is blocked by excess unlabeled uPA (lane 2). A much higher molecular weight band at the top of the gel may represent binding of uPA to inhibitors produced by the cells themselves. This point was not explored further. In contrast, in the presence of cells, iodinated DFP-uPA remained a single 55-kD band. By $24 \mathrm{~h}$, active 55-kD uPA was no longer present in the conditioned media (lane 5) unless excess unlabeled uPA was added (lane 6). A small amount of residual iodinated enzyme

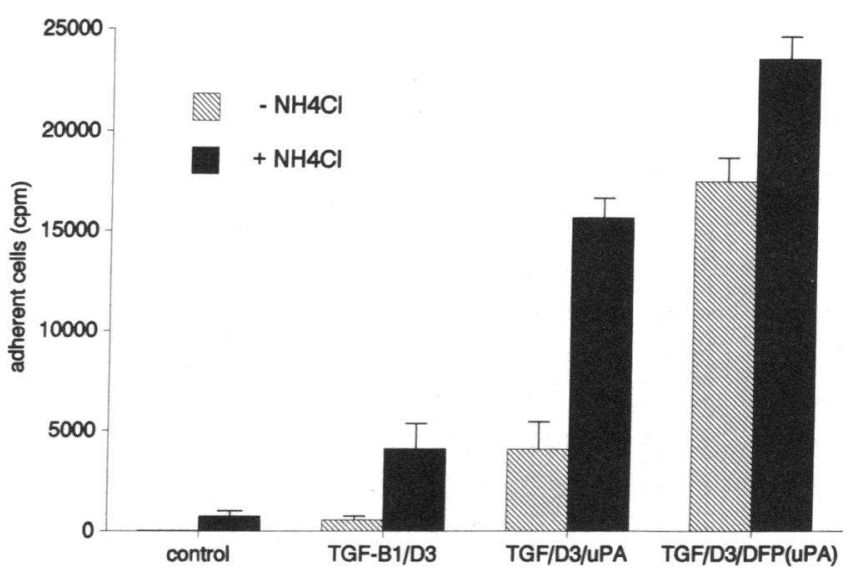

Figure 7. Effect of $\mathrm{NH}_{4} \mathrm{Cl}$ on TGF- $\beta 1 / \mathrm{D}_{3} \mathrm{U} 937$ cell adherence. Cells were incubated in the absence or presence of $50 \mathrm{nM}$ vitamin $\mathrm{D}_{3}, 1$ $\mathrm{ng} / \mathrm{ml} \mathrm{TGF}-\beta 1,3 \mathrm{nM}$ uPA or DFP-uPA, and $10 \mathrm{mM} \mathrm{NH}_{4} \mathrm{Cl}$ as indicated in the figure for $24 \mathrm{~h}$ and adherence was determined. The mean values \pm the $S D$ of three separate experiments each performed in triplicate are given.

can be seen at $\approx 90 \mathrm{kD}$ in lane 5 ; this most likely represents uPA/PAI complex. The amount of DFP-uPA in the absence of excess cold uPA has also decreased (lane 7). These observations were paralleled by an increase in TCA soluble counts at $24 \mathrm{~h}$ in media without excess unlabeled uPA: The amount of TCA soluble counts was greater in media containing active ${ }^{125} \mathrm{I}-\mathrm{uPA}$ than in media containing DFP- ${ }^{125} \mathrm{I}$-uPA (data not shown).

The amount of iodinated UPA on the cell surface under the various culture conditions is shown in Fig. $8 \mathrm{~B}$. The presence of 55-kD active uPA and DFP-uPA can be seen at $2 \mathrm{~h}$ (lanes 1 and 2); active uPA but not DFP-uPA is also present in a higher molecular mass band $\approx 90 \mathrm{kD}$. By $24 \mathrm{~h}$ (lane 3 ) there is no active enzyme detectable on the cell surface; the presence of $\mathrm{NH}_{4} \mathrm{Cl}$ (lane 4) partially restored surface-elutable uPA. The amount of DFP-uPA on the cell surface at $24 \mathrm{~h}$ is also relatively increased by $\mathrm{NH}_{4} \mathrm{Cl}$ (lanes 6 vs. 5 ). These data at $24 \mathrm{~h}$ parallel the adherence data seen with the addition of $\mathrm{NH}_{4} \mathrm{Cl}$ in Fig. 7, although the increase in adherence $(1.2 \times)$ is less than the increase in cell-surface DFP-uPA as determined by computer-assisted densitometry $(1.8 \times)$. This observation may be explained by the fact that the concentration of ${ }^{125} \mathrm{I}$-DFP-uPA added for determination of turnover was less than that required for adherence. In additional experiments it was observed that clearance of iodinated UPA precomplexed with PAI-1 before co-culture with cells is virtually the same as that seen with active uPA alone. These results are similar to the adherence data given in Fig. $6 A$ in which the addition of active uPA and uPA precomplexed with PAI-1 were functionally equivalent in promoting adhesion, indicating that active uPA when added to these cells becomes complexed with PAI and ultimately cleared from the cell surface.

\section{Discussion}

Previous reports have outlined two distinct functions of uPA bound to its receptor in monocyte/macrophage biology: a catalytic role important in generating pericellular proteolysis and a noncatalytic signaling function operative in the differentiation and adhesion of phorbol diester-stimulated monocytic pro- 

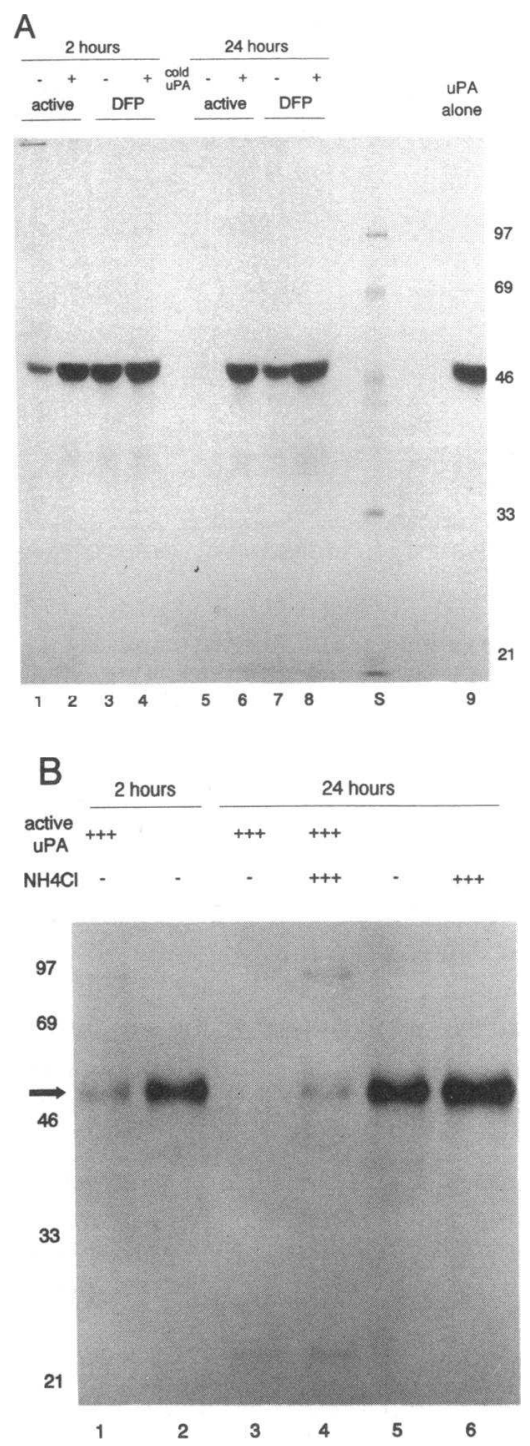
raphy.

genitors (31). Data presented here not only confirm these observations but also extend them in several important respects. First, we show that physiological cytokines such as vitamin $D_{3}$, TGF- $\beta 1$, and GM-CSF also induce uPA-dependent adhesiveness in human leukemic cell lines (Table I). Further, cells prestimulated with cytokines become adherent rapidly upon addition of UPA (Fig. 1) and the concentration of UPA inducing half-maximal adherence is very near the $K_{\mathrm{d}}$ for uPA binding to uPAR. Finally, this potential for adhesion is reversible and dependent on the continued occupation of the uPA receptor. The need for continued receptor occupation suggests that cytokine-induced adhesiveness is regulated not only by the expression of UPA receptor and the availability of ligand, but also by factors that modulate $\mathrm{UPA}$ receptor turnover. One such factor identified in our study is the presence of PAI-1, which not only abrogates proteolytic activity but also decreases adhesiveness. The ability of a single molecule to regulate both proteolysis and adhesiveness makes it likely that the two apparently distinct functions of UPA in monocyte/macrophage biology are in fact intrinsically linked.
None of the cytokines tested, namely vitamin $\mathrm{D}_{3}, \mathrm{TGF}-\beta 1$, IFN-gamma, IL-6, GM-CSF, M-CSF, and TNF- $\alpha$, induced strong adherence at $24 \mathrm{~h}$ in the absence of exogenous uPA. This was true in TGF- $\beta 1 / D_{3}$-primed cells despite expression of uPA and upregulation of uPA receptor (Figs. 2 and 3). Several lines of evidence indicate that the interaction of endogenous uPA with endogenously produced PAI followed by turnover of the UPA/PAI complex may account for part or all of this lack of adherence. DFP-uPA or an amino-terminal fragment of uPA, which do not bind PAI, were severalfold more effective than active uPA at inducing adherence of cytokine-stimulated cells (Fig. 4) and a mAb directed against the active site of uPA, which may interfere with uPA/PAI complex formation, enhanced uPA-dependent adherence (Fig. 5). Further, addition of anti-PAI-1 antibodies to cytokine-stimulated cells in the absence of exogenous uPA increased the adherence of these cells, although the amount of adherence seen was small (Fig. $6 \mathrm{~B}$ ). Finally, disruption of lysosomal acidification promoted adhesion of TGF- $\beta 1 / D_{3}$-stimulated cells and this correlated with the appearance of both 55-kD uPA and uPA/PAI complex on the cell surface (Figs. 7 and 8 ). It is also possible that insufficient local concentrations of UPA are produced by the cells in culture, as adhesion required low nM concentrations of uPA. In either case, the fact that none of the tested cytokines induced strong adherence in the absence of exogenous uPA indicates that paracrine sources of UPA may be important for the in vivo adherence of monocytic cells under the influence of these cytokines.

Although it appears that PAI-1 is the major regulator of uPA turnover and cellular adherence in TGF- $\beta 1 / D_{3}$-stimulated U937 cells, we cannot exclude a role for PAI-2. It is possible, even likely, that there is some PAI-2 present at $24 \mathrm{~h}$ in conditioned medium from these cells and the anti-PAI-2 antibodies, having only weak neutralizing activity, may not have blocked PAI-2 activity in Fig. $6 \mathrm{~B}$. However, they had no effect over a wide concentration range. Even if PAI- 2 does not play a major role in TGF- $\beta 1 / D_{3}$-stimulated U937 cells, uPA/PAI-2 complex turnover has been documented in other myeloid cells (12) and it is possible that PAI-2 may be the dominant regulator of uPA turnover in other settings. Regulation of uPA/PAI turnover is incompletely understood, although a recent report indicates a role for the alpha-2-macroglobulin receptor in controlling the turnover of the uPA/PAI-1 complex bound to uPAR of monocytes (50).

It is interesting that cytokine-primed cells, despite nonadherence at $24 \mathrm{~h}$, are capable of rapid adherence and morphological changes upon exposure to uPA (Fig. 1). Indeed, the concentration of uPA required for half-maximal adherence when added at $24 \mathrm{~h}(0.1-0.3 \mathrm{nM})$ correlates well with the measured cell-associated binding affinity for uPA under these conditions $(0.33 \mathrm{nM})$. These data suggest the presence of a uPA-dependent adhesive mechanism that is upregulated by cytokine priming. This mechanism is likely a complex phenomenon involving factors such as adhesive membrane proteins, the cytoskeleton, etc. Indeed, a strict correlation between cell-associated uPA binding and uPA-dependent adherence was not seen ( Table I). Although stimulation with vitamin $\mathrm{D}_{3}$ did not increase uPA binding, it did increase uPA-dependent adherence over that of stock unstimulated cells. In addition, although TGF- $\beta 1$ and GM-CSF induced similar increases in uPA binding, uPA-dependent adherence after GM-CSF stimulation was 1.5 times that of TGF- $\beta 1$. 
The nature of the uPA-dependent adhesive signaling mechanism is unclear. The only known uPA receptor is linked to the membrane by a glycosyl-phosphatidylinositol (GPI) membrane anchor (51). Ciliary neurotrophic factor receptor, another GPI-linked receptor, has been shown to participate in signaling despite the lack of an intracytoplasmic domain. This receptor has partial sequence homology with the IL-6 receptor (52), which may transduce its signal by coupling to a nonligand-binding glycoprotein, gp130 (53, 54). Further, GPIlinked receptor proteins have been shown to associate with protein kinases (55). These reports provide precedence for a possible mechanism by which GPI-linked receptors such as the uPA receptor may participate in signal transduction.

Of note at $24 \mathrm{~h}$ is a low molecular mass cell-surface protein present at $\approx 22 \mathrm{kD}$ in cells exposed to active uPA (Fig. $8 \mathrm{~B}$ ). This band may represent an amino-terminal fragment of uPA known to exist as a naturally occurring protein in human urine (56). Its presence may explain at least in part the ability of active uPA to induce a signal for adherence despite active turnover. Amino-terminal portions of the uPA molecule containing only the receptor-binding domain induce adherence in cytokine-primed cells. The absence of this protein on DFP-uPAexposed cells suggests that processing of uPA, possibly during turnover in association with PAI, results in production of this fragment. It is not known if U937 cells possess an endogenous pathway for generation of an amino-terminal fragment of uPA and, if so, what the role of such a fragment in cellular adherence may be. This is a subject for future study.

This study provides evidence for clearance of both active and DFP-inactivated uPA from the cell surface (Fig. 8). This contrasts with an earlier report (47), where little degradation of active uPA or DFP-uPA was seen in U937 cells. Two significant differences in methodology exist between the present report and the previous one. The present experiments used cytokine-stimulated rather than unstimulated cells and the time period of observation was extended to $24 \mathrm{~h}$ rather than $3 \mathrm{~h}$. Either or both of these differences may explain the apparent discrepancy in results. The previous report also presented data that lysosomal degradation was important in the turnover of uPA/PAI-1 complexes from the uPA receptor: The present study extends these observations by confirming an increase in cell-surface-bound uPA and DFP-uPA (Fig. $8 \mathrm{~B}$ ) under conditions in which lysosomal degradation is impeded, and by showing a functional correlate of changes in surface-bound uPA.

The observations presented here expand on the known functions of UPA and PAI in localized extracellular proteolysis by providing evidence of a regulatory role for the interaction of UPA and PAI in cellular adherence. Although we have not specifically studied migration and the adhesive mechanisms are undefined, possible implications of these findings for cellular migration through the extracellular matrix are as follows. The production of uPA by the cell and subsequent binding to its cell surface receptor focuses proteolytic activity at the leading edge of the cell and also results in local cellular adherence while proteolysis of the local extracellular matrix takes place. PAI-1, released from binding to vitronectin in the extracellular matrix (57) or produced by the cell under the influence of cytokines, and / or PAI-2, complexes with uPA, effectively abrogating proteolytic activity. The turnover of the uPA/PAI complex then occurs, simultaneously removing the stimulus for strong adherence, thus allowing migration and clearing the uPA receptor so that new or recycled receptors can again bind active uPA to continue extracellular matrix proteolysis at a new site. An implication of this hypothesis is that receptor-binding fragments of the urokinase molecule that are neither proteolytically active nor rapidly cleared from the uPA receptor could interfere with migration of monocytic cells and thus be used to modulate inflammatory processes in which monocyte/macrophage accumulation is prominent. Future studies are necessary to test directly the influence of receptor-bound but inactive uPA on cellular migration.

\section{Acknowledgments}

The authors thank Dr. A. Roomi Nusrat for many helpful discussions; Guo-Ping Shi for able technical assistance; Drs. Jack Henkin, Andrew Mazar, T. C. Wun, Robert Broeze, and Lester Kobzik for generous gifts of reagents; and Dr. Jeffrey Drazen for critical review of the manuscript.

This study was supported by National Institutes of Health Training grant HL-07633, NIH grant HL-44712, and grant 2289 from the Council for Tobacco Research.

\section{References}

1. Van Furth, R. 1982. Current view on the mononuclear phagocyte system Immunobiology. 161:178-185.

2. Gamble, J. R., M. J. Elliot, E. Jaipargas, A. F. Lopez, and M. A. Vadas. 1989. Modulation of human monocyte adherence by granulocyte-macrophage colony-stimulating factor. Proc. Natl. Acad. Sci. USA. 86:7169-7173.

3. Polla, B. S., A. M. Healy, E. P. Amento, and S. M. Krane. 1986. 1,25-Dihydroxyvitamin $D_{3}$ maintains adherence of human monocytes and protects them from thermal injury. J. Clin. Invest. 77:1332-1339.

4. Singer, S. J., and A. Kupfer. 1986. The directed migration of eukaryotic cells. Annu. Rev. Cell Biol. 2:337-365.

5. Lauffenburger, D. A. 1991. Models for receptor-mediated cell phenomena: adhesion and migration. Annu. Rev. Biophys. Biophys. Chem. 20:387-414.

6. Anderson, D. C., and T. A. Springer. 1987. Leukocyte adhesion deficiency: an inherited defect in the Mac-1, LFA-1, and p150,95 glycoproteins. Annu. Rev. Med. 38:175-194.

7. Vassalli, J.-D., J.-D. Dayer, A. Wohlwend, and D. Belin. 1984. Concomitant secretion of prourokinase and of a plasminogen activator-specific inhibitor by cultured human monocytes-macrophages. J. Exp. Med. 159:1653-1668.

8. Alving, B. M., C. Krishnamurti, Y.-P. Liu, D. L. Lucas, and D. G. Wright 1988. Stimulated production of urokinase and plasminogen activator inhibitor-2 by the human promyelocytic leukemia cell line HL-60. Thromb. Res. 51:175185.

9. Gyetko, M. R., A. C. Webb, and R. G. Sitrin. 1988. Modulation of urokinase-type plasminogen activator and plasminogen activator inhibitor-2 expression by U-937 mononuclear phagocytes: effects of 1,25-dihydroxyvitamin $D_{3}$ and phorbol ester. J. Immunol. 141:2693-2698.

10. Vassalli, J.-D., D. Baccino, and D. Belin. 1985. A cellular binding site for the $M_{r} 55,000$ form of the human plasminogen activator, urokinase. J. Cell Biol. 100:86-92.

11. Nielsen, L. S., G. M. Kellerman, N. Behrendt, R. Picone, K. Dano, and F. Blasi. 1988. A $55,000-60,000 \mathrm{M}_{\mathrm{r}}$ receptor protein for urokinase-type plasminogen activator: identification in human tumor cell lines and partial purification. $J$. Biol. Chem. 263:2358-2363.

12. Estreicher, A., J. Muhlhauser, J.-L. Carpentier, L. Orci, and J.-D. Vassalli. 1990. The receptor for urokinase-type plasminogen activator polarizes expression of the protease to the leading edge of migrating monocytes and promotes degradation of enzyme inhibitor complexes. J. Cell Biol. 111:783-792.

13. Kirchheimer, J. C., and H. G. Remold. 1989. Endogenous receptor-bound urokinase mediates tissue invasion of human monocytes. J. Immunol. 143:26342639.

14. Alessi, M. C., P. J. Declerck, M. De Mol, L. Nelles, and D. Collen. 1988. Purification and characterization of natural and recombinant human plasminogen activator inhibitor-1 (PAI-1). Eur. J. Biochem. 175:531-540.

15. Cubellis, M. V., P. Andreasen, P. Ragno, M. Mayer, K. Dano, and F. Blasi. 1989. Accessibility of receptor-bound urokinase to type-1 plasminogen activator inhibitor. Proc. Natl. Acad. Sci. USA. 86:4828-4832.

16. Kirchheimer, J. C., and H. G. Remold. 1989. Functional characteristics of receptor-bound urokinase on human monocytes: catalytic efficiency and susceptibility to inactivation by plasminogen activator inhibitors. Blood. 74:1396-1402.

17. Ellis, V., T.-C. Wun, N. Behrendt, E. Ronne, and K. Dano. 1990. Inhibition of receptor-bound urokinase by plasminogen-activator inhibitors. J. Biol. Chem. 265:9904-9908. 
18. Kirchheimer, J. C., B. R. Binder, and H. G. Remold. 1990. Matrix-bound plasminogen activator inhibitor type 1 inhibits the invasion of human monocytes into interstitial tissue. J. Immunol. 145:1518-1522.

19. Plow, E. F., D. E. Freaney, J. Plescia, and L. A. Miles. 1986. The plasminogen system and cell surfaces: evidence for plasminogen and urokinase receptors on the same cell type. J. Cell Biol. 103:2411-2420.

20. Vaheri, A., R. W. Stephens, E.-M. Salonen, J. Pollanen, and H. Tapiovaara. 1990. Plasminogen activation at the cell surface-matrix interface. Cell Differ. Dev. 32:255-262.

21. Harris, P., and P. Ralph. 1985. Human leukemic models of myelomonocytic development: a review of the HL-60 and U937 cell lines. J. Leukocyte Biol. 37:407-422.

22. Lubbert, M., F. Herrmann, and H. P. Koeffler. 1991. Expression and regulation of myeloid-specific genes in normal and leukemic myeloid cells. Blood. 77:909-924.

23. Amento, E. P., A. K. Bhalla, J. T. Kurnick, R. L. Kradin, T. L. Clemens, S. A. Holick, M. F. Holick, and S. M. Krane. 1984. $1 \alpha, 25$-Dihydroxyvitamin $\mathrm{D}_{3}$ induces maturation of the human monocyte cell line U937, and, in association with a factor from human $\mathrm{T}$ lymphocytes, augments production of the monokine, mononuclear cell factor. J. Clin. Invest. 73:731-739.

24. Rigby, W. F., C. L. Shen, E. D. Ball, P. M. Guyre, and M. W. Fanger. 1984. Differentiation of a human monocytic cell line by 1,25-dihydroxyvitamin $\mathrm{D}_{3}$ (calcitriol): a morphologic, phenotypic, and functional analysis. Blood. 64:1110-1115.

25. Weinberg, J. B., and J. W. Larrick. 1987. Receptor-mediated monocytoid differentiation of human promyelocytic cells by tumor necrosis factor: synergistic actions with interferon-gamma and 1,25-dihydroxyvitamin $\mathrm{D}_{3}$. Blood. 70:9941002

26. Zuckerman, S. H., Y. M. Surprenant, and J. Tang. 1988. Synergistic effect of ganulocyte-macrophage colony-stimulating factor and 1,25-dihydroxyvitamin $D_{3}$ on the differentiation of the human monocytic cell line U937. Blood. 71:619624.

27. Zuckerman, S. H., and R. D. Schreiber. 1988. Up-regulation of gamma interferon receptors on the human monocytic cell line U937 by 1,25-dihydroxyvitamin $\mathrm{D}_{3}$ and granulocyte-macrophage colony-stimulating factor. J. Leukocyte Biol. 44:187-191.

28. Kelsey, S. M., H. L. J. Makin, M. G. Macey, and A. C. Newland. 1990. Gamma interferon augments functional and phenotypic characteristics of vitamin $\mathrm{D}_{3}$-induced monocytoid differentiation in the U937 human leukemic cell line. Leuk. Res. 14:1027-1033.

29. Morikawa, M., N. Harada, G.-I. Soma, and T. Yoshida. 1990. Transforming growth factor- $\beta 1$ modulates the effect of $1 \alpha, 25$-dihydroxyvitamin $\mathrm{D}_{3}$ on leukemic cells. In Vitro Cell Dev. Biol. 26:682-690.

30. Kirchheimer, J. C., Y.-H. Nong, and H. G. Remold. 1988. IFN-gamma, tumor necrosis factor-alpha, and urokinase regulate the expression of urokinase receptors on human monocytes. J. Immunol. 141:4229-4234.

31. Nusrat, A. R., and H. A. Chapman, Jr. 1991. An autocrine role for urokinase in phorbol ester-mediated differentiation of myeloid cell lines. J. Clin. Invest. 87:1091-1097.

32. Chapman, H. A., P. Bertozzi, L. Z. Sailor, and A. R. Nusrat. 1990. Alveolar macrophage urokinase receptors localize enzyme activity to the cell surface. Am. J. Physiol. 259:L432-L438.

33. Bertozzi, P., B. Astedt, L. Zenzius, K. Lynch, F. LeMaire, W. Zapol, and H. A. Chapman, Jr. 1990. Depressed bronchoalveolar urokinase activity in patients with adult respiratory distress syndrome. $N$. Engl. J. Med. 322:890-897.

34. Chirgwin, J. M., A. E. Przybyla, R. J. MacDonald, and W. J. Rutter. 1979. Isolation of biologically active ribonucleic acid from sources enriched in ribonuclease. Biochemistry. 18:5294-5299.

35. Chapman, H. A., X. Yang, L. Z. Sailor, and D. J. Sugarbaker. 1990. Developmental expression of plasminogen activator inhibitor type 1 by human alveolar macrophages: possible role in lung injury. J. Immunol. 145:3398-3405.

36. Munger, J. S., G.-P. Shi, E. A. Mark, D. T. Chin, C. Gerard, and H. A. Chapman. 1991. A serine esterase released by human alveolar macrophages is closely related to liver microsomal carboxylesterases. J. Biol. Chem. 266:1883218838.

37. Granelli-Piperno, A., and E. Reich. 1978. A study of proteases and protease-inhibitor complexes in biological fluids. J. Exp. Med. 148:223-234.

38. Hekman, C. M., and D. J. Loskutoff. 1985. Endothelial cells produce a latent inhibitor of plasminogen activators that can be activated by denaturants. $J$ Biol. Chem. 260:11581-11587.

39. Unkeless, J., K. Dano, G. M. Kellerman, and E. Reich. 1974. Fibrinolysis associated with oncogene transformation: partial purification and characterization of the cell factor, a plasminogen activator. J. Biol. Chem. 249:4295-4305.

40. Stoppelli, M. P., C. Tacchetti, M. V. Cubellis, A. Corti, V. J. Hearing, G. Cassani, E. Appella, and F. Blasi. 1986. Autocrine saturation of pro-urokinase receptors on human A431 cells. Cell. 45:675-684.

41. Colton, T. 1974. Statistics in Medicine. Little, Brown, \& Company, Boston.

42. Miyaura, C., K. Onozaki, Y. Akiyama, T. Taniyama, T. Hirano, T. Kishimoto, and T. Suda. 1988. Recombinant human interleukin 6 (B-cell stimulatory factor 2) is a potent inducer of differentiation of mouse myeloid leukemia cells (M1). FEBS (Fed. Eur. Biochem. Soc.) Lett. 234:17-21.

43. Young, D. A., L. D. Lowe, and S. C. Clark. 1990. Comparison of the effects of IL-3, granulocyte-macrophage colony-stimulating factor, and macrophage colony-stimulating factor in supporting monocyte differentiation in culture: analysis of macrophage antibody-dependent cellular cytotoxicity. $\mathrm{J}$. Immunol. 145:607-615.

44. Lund, L. R., E. Ronne, A. L. Roldan, N. Behrendt, J. Romer, F. Blasi, and K. Dano. 1991. Urokinase receptor mRNA level and gene transcription are strongly and rapidly increased by phorbol myristate acetate in human monocytelike U937 cells. J. Biol. Chem. 266:5177-5181.

45. Stoppelli, M. P., A. Corti, A. Soffientini, G. Cassani, F. Blasi, and R. K Assoian. 1985. Differentiation-enhanced binding of the amino-terminal fragment of human urokinase plasminogen activator to a specific receptor on U937 monocytes. Proc. Natl. Acad. Sci. USA. 82:4939-4943.

46. Appella, E., E. A. Robinson, S. J. Ullrich, M. P. Stoppelli, A. Corti, G. Cassani, and F. Blasi. 1987. The receptor-binding sequence of urokinase: a biological function for the growth-factor module of proteases. J. Biol. Chem. 262:44374440

47. Cubellis, M. V., T.-C. Wun, and F. Blasi. 1990. Receptor-mediated internalization and degradation of urokinase is caused by its specific inhibitor PAI-1. EMBO (Eur. Mol. Biol. Organ.) J. 9:1079-1085.

48. Olson, D., J. Pollanen, G. Hoyer-Hansen, E. Ronne, K. Sakaguchi, T.-C. Wun, E. Appella, K. Dano, and F. Blasi. 1992. Internalization of the urokinaseplasminogen activator inhibitor type-1 complex is mediated by the urokinase receptor. J. Biol. Chem. 267:9129-9133.

49. Ohkuma, S., and B. Poole. 1978. Fluorescence probe measurement of the intralysosomal $\mathrm{pH}$ in living cells and the perturbation of $\mathrm{pH}$ by various agents. Proc. Natl. Acad. Sci. USA. 75:3327-3331.

50. Nykjaer, A., C. M. Petersen, B. Moller, P. H. Jensen, S. K. Moestrup, T. L. Holtet, M. Etzerodt, H. C. Thogersen, M. Munch, P. A. Andreasen, et al. 1992 Purified alpha-2-macroglobulin receptor/LDL receptor-related protein binds urokinase-plasminogen activator inhibitor type-1 complex; evidence that the alpha-2-macroglobulin receptor mediates cellular degradation of urokinase receptor-bound complexes. J. Biol. Chem. 267:14543-14546.

51. Ploug, M., E. Ronne, N. Behrendt, A. L. Jensen, F. Blasi, and K. Dano. 1991. Cellular receptor for urokinase plasminogen activator: carboxyl-terminal processing and membrane anchoring by glycosyl-phosphatidylinositol. J. Biol. Chem. 266:1926-1933.

52. Davis, S., T. H. Aldrich, D. M. Valenzuela, V. Wong, M. E. Furth, S. P. Squinto, and G. D. Yancopoulos. 1991. The receptor for ciliary neurotrophic factor. Science (Wash. DC). 253:59-63.

53. Taga, T., M. Hibi, Y. Hirata, K. Yamasaki, K. Yasukawa, T. Matsuda, T. Hirano, and T. Kishimoto. 1989. Interleukin-6 triggers the association of its receptor with a possible signal transducer, gp130. Cell. 58:573-581.

54. Hibi, M., M. Murakami, M. Saito, T. Hirano, T. Taga, and T. Kishimoto. 1990. Molecular cloning and expression of an IL-6 signal transducer, gp130. Cell. 63:1149-1157.

55. Stefanova, I., V. Horejsi, I. J. Ansotegui, W. Knapp, and H. Stockinger 1991. GPI-anchored cell-surface molecules complexed to protein tyrosine kinases. Science (Wash. DC). 254:1016-1019.

56. Holmberg, L., B. Bladh, and B. Astedt. 1976. Purification of urokinase by affinity chromatography. Biochim. Biophys. Acta. 445:215-222.

57. Salonen, E.-M., A. Vaheri, J. Pollanen, R. Stephens, P. Andreasen, M. Mayer, K. Dano, J. Gailit, and E. Ruoslahti. 1989. Interaction of plasminogen activator inhibitor (PAI-1) with vitronectin. J. Biol. Chem. 264:6339-6343. 